K/TCD-1141
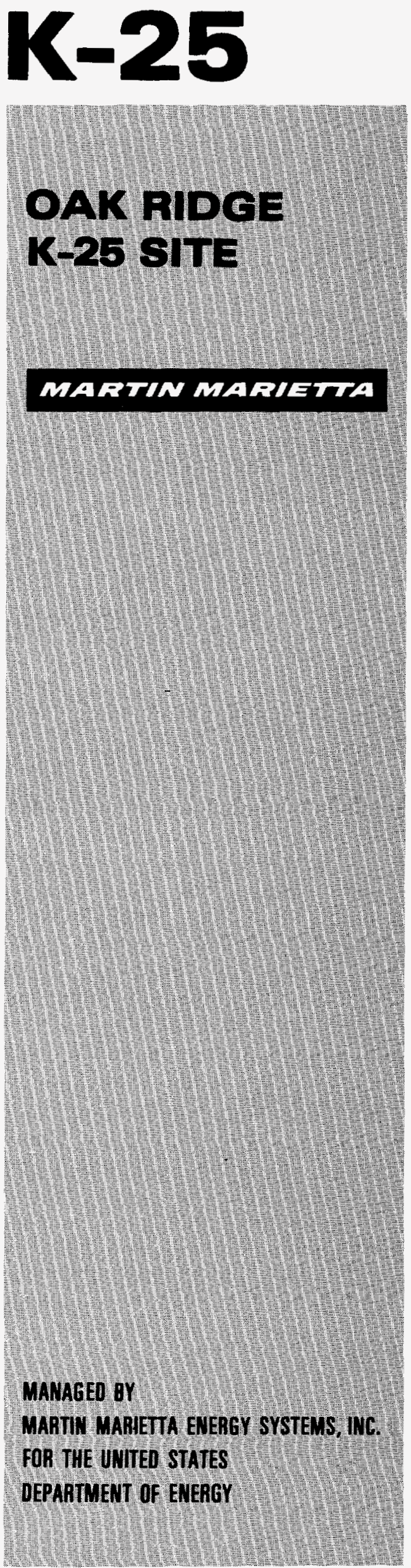

Removal of Technetium-99 from Simulated Oak Ridge National Laboratory Newly-Generated Liquid Low-Level Waste

\author{
K-25 Technical Division \\ W. D. Bostick \\ P. E. Osborne \\ D. E. Beck \\ D. H. Bunch \\ R. L. Fellows \\ G. F. Sellers \\ J. L. Shoemaker
}

Science \& Engineering Rerearch Semester Participant

K. T. Bowser

ORNL Chemical Technology Division D. T. Bostick 


\section{DISCLAIMER}

This report was prepared as an account of work sponsored by an agency of the United States Government. Neither the United States Government nor any agency thereof, nor any of their employees, makes any warranty, express or implied, or assumes any legal liability of responsibility for the accuracy, completeness, or usefulness of any information, apparatus, product, or process disclosed, or represents that its use would not infringe privately owned rights. Reference herein to any specific commercial product, process, or service by trade name, trademark, manufacturer, or otherwise, does not necessarily constitute or imply its endorsement, recommendation, or favoring by the United States Government or any agency thereof. The views and opinions of authors expressed herein do not necessarily state or reflect those of the United States Government or any agency thereof. 


\section{DISCLAIMER}

Portions of this document may be illegible in electronic image products. Images are produced from the best available original document. 


\title{
Removal of Technetium-99 from Simulated Oak Ridge National Laboratory Newly-Generated Liquid Low-Level Waste
}

\author{
K-25 Technical Division \\ W. D. Bostick (Principal Investigator) \\ D. E. Beck \\ P. E. Osborne \\ D. H. Bunch \\ R. L. Fellows \\ G. F. Sellers \\ J. L. Shoemaker \\ Science \& Engineering Research Semester Participant \\ K. T. Bowser \\ ORNL Chemical Technology Division \\ D. T. Bostick
}

Date published: June 1995

Prepared by the

OAK RIDGE K-25 SITE

Oak Ridge, Tennessee 37831-7101

managed by

MARTIN MARIETTA ENERGY SYSTEMS, INC.

for the

This document haspeen approved for release U.S. DEPARTMENT OF ENERGY

The public by:

mder contract DE-AC05-840R21400 


\section{CONTENTS}

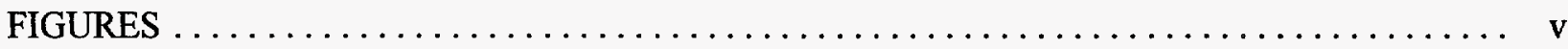

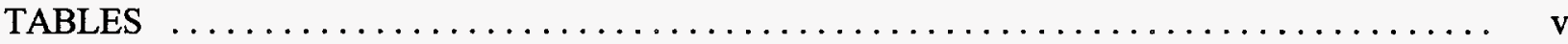

1. EXECUTIVE SUMMARY $\ldots \ldots \ldots \ldots \ldots \ldots \ldots \ldots \ldots \ldots \ldots \ldots \ldots \ldots \ldots \ldots \ldots$

2. INTRODUCTION $\ldots \ldots \ldots \ldots \ldots \ldots \ldots \ldots \ldots \ldots \ldots \ldots \ldots \ldots \ldots \ldots \ldots \ldots \ldots$

2.1 NEWLY GENERATED LIQUID LOW-LEVEL WASTE AT OAK RIDGE

NATIONAL LABORATORY $\ldots \ldots \ldots \ldots \ldots \ldots \ldots \ldots \ldots \ldots \ldots \ldots \ldots \ldots \ldots \ldots \ldots \ldots \ldots$

3. METHODS AND MATERIALS $\ldots \ldots \ldots \ldots \ldots \ldots \ldots \ldots \ldots \ldots \ldots \ldots \ldots \ldots \ldots \ldots \ldots \ldots \ldots$

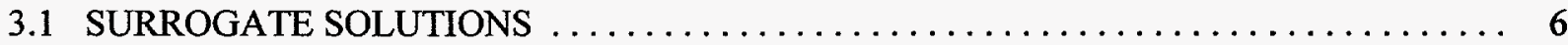

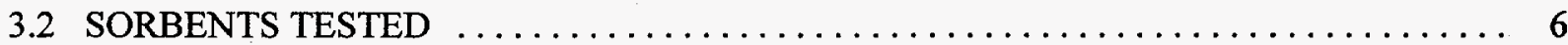

3.3 EQUILIBRIUM ISOTHERM TESTING AND LIQUID SCINTILLATION TESTING $\ldots \ldots \quad \mathbf{8}$

3.4 PACKED-COLUMN ELUATE BREAKTHROUGH STUDIES $\ldots \ldots \ldots \ldots \ldots \ldots \ldots \ldots .8$

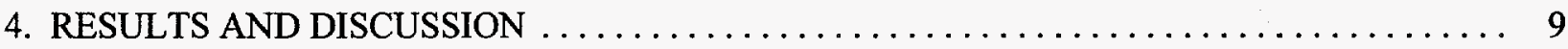

4.1 EQUILIBRIUM SORPTION ISOTHERMS $\ldots \ldots \ldots \ldots \ldots \ldots \ldots \ldots \ldots \ldots \ldots \ldots$

4.2 PACKED COLUMN BREAKTHROUGH STUDIES: DOWEX ${ }^{\mathrm{TM}} 1-\mathrm{X}-\mathbf{8} \ldots \ldots \ldots \ldots \ldots 11$

4.3 PACKED COLUMN BREAKTHROUGH STUDIES: STEEL WOOL $\ldots \ldots \ldots \ldots \ldots \ldots 15$

5. CONCLUSIONS \& RECOMMENDATIONS $\ldots \ldots \ldots \ldots \ldots \ldots \ldots \ldots \ldots \ldots \ldots \ldots \ldots$

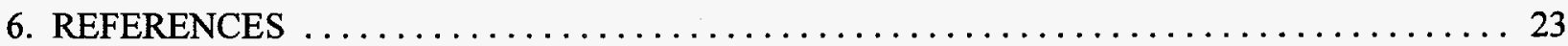


• 


\section{FIGURES}

1 Adsorbent Removal efficiency as a Function of $\mathrm{pH}(0.01 \mathrm{~g}$ as-received adsorbent $/ \mathrm{mL}$ simulated

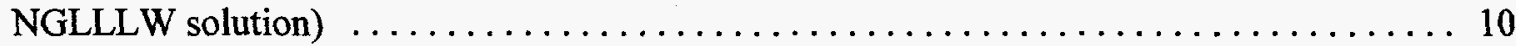

2 Linear sorption isotherm data for removal of soluble ${ }^{99} \mathrm{Tc}$ in Simulated NGLLLW "Solution A" by

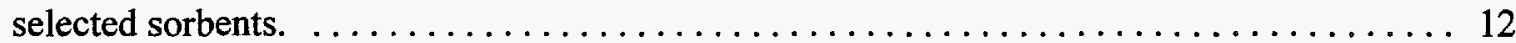

3 Linear sorption isotherm data for removal of soluble ${ }^{99} \mathrm{Tc}$ in Simulated NGLLLW "Solution B" by

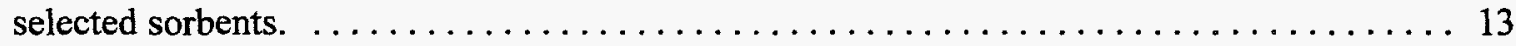

4 Breakthrough of ${ }^{99} \mathrm{Tc}$ from Dowex ${ }^{\mathrm{TM}}$ 1-X-8 Resin Under Dynamic Flow (Influent: Simulated NGLLLW "Solution B"). [ $0.83 \mathrm{GPM} / \mathrm{ft}^{2}$ (cross-sectional area); nominal column residence time

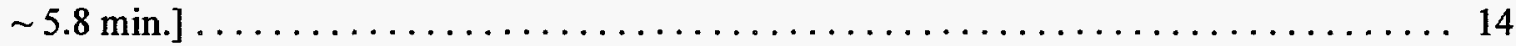

5 Breakthrough of ${ }^{99} \mathrm{Tc}$ from Packed-Bed Columns Under Dynamic Flow: Dowex ${ }^{\mathrm{TM}} 1-\mathrm{X}-8$, Reillex ${ }^{\mathrm{TM}}$ HPQ, and Fisher I-57 Iron Filings Under Dynamic Flow (Influent: Simulated Portsmouth Gaseous Diffusion Plant Heavy Metals Filtrate). From Del Cul and Bostick (1995). . . . . . . 16

6 Breakthrough of Mercury from Kodak Steel Wool Under Dynamic Flow (Influent: $\mathrm{HgCl}_{2}$ solution, traced with ${ }^{203} \mathrm{Hg}$ ). $\left[\sim 0.15 \mathrm{GPM} / \mathrm{ft}^{2}\right.$ (cross-sectional area); nominal column residence time $\sim 12 \mathrm{~min}$.]

Dynamic Flow Elution for ${ }^{99} \mathrm{Tc}$ from Kodak Steel Wool (Influent: Simulated NGLLLW "Solution $\mathrm{B}^{\prime \prime}$. [ $0.45 \mathrm{GPM} / \mathrm{ft}^{2}$ (cross-sectional area); nominal column residence time $\sim 9.2 \mathrm{~min}$.] $\ldots 18$

\section{TABLES}

3 Analysis of Surrogate Wastewater Preparations 


\section{EXECUTIVE SUMMARY}

We report laboratory investigations on treatment options for the removal of the radionuclide ${ }^{99} \mathrm{Tc}$ (as the pertechnetate anion, $\mathrm{TcO}_{4}^{-}$) from simulated Oak Ridge National Laboratory Newly Generated Liquid LowLevel Waste. The waste stimulant is alkaline ( $\mathrm{pH} 12-13)$, containing sodium carbonate $(\sim 0.10 \mathrm{~mol} / \mathrm{L})$ and sodium hydroxide $(\sim 0.125 \mathrm{~mol} / \mathrm{L})$, plus a modest concentration of sodium nitrate $(\sim 0.06 \mathrm{~mol} / \mathrm{L})$. Several organic resin anion exchange media were tested; Dowex ${ }^{\mathrm{TM}} 1-\mathrm{X}-8$ and Reillex ${ }^{\mathrm{TM}}$ HPQ resins were notably effective (with equilibrium distribution coefficients $\sim 2,000 \mathrm{~mL} / \mathrm{g}$, as-received basis). We also tested steel wool as a reagent to chemically reduce and sorb ${ }^{99} \mathrm{Tc}$. At $\mathrm{pH}$ values above $\sim 10$, the iron surface was passivated and became ineffective as a reagent for technetium; however, as the test solution $\mathrm{pH}$ value was adjusted to near-neutrality (e.g., $\mathrm{pH} \mathrm{8-9),} \mathrm{the} \mathrm{steel} \mathrm{was} \mathrm{noted} \mathrm{to} \mathrm{be} \mathrm{more} \mathrm{effective} \mathrm{than} \mathrm{the} \mathrm{organic} \mathrm{resins}$ tested.

In dynamic flow conditions, steel wool packed in a column was noted to continuously leak $\sim 1-3 \%$ of the amount of ${ }^{99} \mathrm{Tc}$ activity in the feed solution, although no additional increase in eluent activity was noted for the duration of the testing ( $\sim 1200$ bed volumes of $\sim 0.11 \mathrm{mg} / \mathrm{L}{ }^{99} \mathrm{Tc}$ flowed at a rate equivalent to $\sim 0.5$ $\mathrm{gal} / \mathrm{min} / \mathrm{ft}^{2}$ of column cross sectional area). Although no breakthrough was noted (other than the 1-3\% continuous 'bleed' noted previously) during the column operation ( $\sim 2$ weeks $)$, the steel in the column was deteriorated, causing plugging and erratic flow toward the end of the testing interval.

Dowex ${ }^{\mathrm{TM}}$ SBR (Dowex ${ }^{\mathrm{TM}} 1-\mathrm{X} 8$, chloride form) was also selected for testing in a packed bed configuration. In contrast to the steel wool experiment, little or no 'bleed' of ${ }^{99} \mathrm{Tc}$ activity was noted in the column effluent (at a flowrate of $\sim 0.8 \mathrm{gal} / \mathrm{min} / \mathrm{ft}^{2}$ of column cross sectional area). During the prolonged testing period, the ${ }^{99} \mathrm{Tc}$ in the column feed was increased from an initial value of $\sim 0.8 \mathrm{mg} / \mathrm{L}$ to a final value of $\sim 23 \mathrm{mg} / \mathrm{L}$. The loading of ${ }^{99} \mathrm{Tc}$ on the resin at an eluant activity of $\sim 1 \%$ of the final feed value corresponded to $\sim 12.3 \mathrm{mg}$ ${ }^{99} \mathrm{Tc}$ per cubic centimeter of bed volume.

It should be noted that loading of ${ }^{99} \mathrm{Tc}$ on Type 1 strongly basic anion exchange resin (such as Dowex ${ }^{\mathrm{TM}}$ $1-\mathrm{X} 8$ ) is adversely affected by high concentrations of competing nitrate ion; this situation could occur if NGLLLW is blended with a relatively large proportion of high-nitrate legacy waste from the Melton Valley Storage Tanks. For aqueous wastes with relatively large concentrations of nitrate, polyvinylpyridine resins (such as Reillex ${ }^{\mathrm{TM}} \mathrm{HPQ}$ ) may yield a higher effective loading capacity (due to greater inherent selectivity for pertechnetate ion in the presence of excess nitrate ion). 


\section{INTRODUCTION}

\subsection{NEWLY GENERATED LIQUID LOW-LEVEL WASTE AT THE OAK RIDGE NATIONAL LABORATORY}

The Oak Ridge National Laboratory (ORNL) has accumulated an inventory of over 350,000 gallons of liquid low-level waste; this waste is currently stored in underground tanks (designated as the Melton Valley Storage Tanks, or MVST). This historic inventory is highly alkaline, and contains relatively high concentrations of nitrate ion ( $>5 \mathrm{~mol} / \mathrm{L}$ in the concentrated supernate), plus appreciable quantities of radionuclides (notably ${ }^{90} \mathrm{Sr}$ and ${ }^{137} \mathrm{Cs}$ ).

Recent improvements in centralized waste treatment have resulted in a waste stream designated Newly Generated Liquid Low-Level Waste (NGLLLW). One contrast to the MVST legacy waste is that the NGLLLW will contain lower concentrations of nitrate ion. In addition to ${ }^{90} \mathrm{Sr}$ and ${ }^{137} \mathrm{Cs}$, significant radionuclides will include ${ }^{106} \mathrm{Ru}$ and ${ }^{99} \mathrm{Tc}$. Principal chemical constituents for the NGLLLW have been reported by Arnold et al. (1994); the composition for a synthetic surrogate solution, based upon current process knowledge and anticipated future laboratory activities, is given in Table 1.

The radionuclide ${ }^{99} \mathrm{Tc}$ has been detected in the MVST waste; a very preliminary estimate gave a value of $\sim 30$ $\mathrm{mg} / \mathrm{L}$, although this value likely reflects analytical interferences and is not necessarily representative of the waste inventory. More recent estimates for ${ }^{99} \mathrm{Tc}$ in MVST filtrate suggest that $1-3 \mathrm{mg} / \mathrm{L}$ may be more credible (Fowler, 1995). Technetium-99 in future NGLLW will originate predominantly as fission product

Table 1. Composition of Simulated NGLLLW ${ }^{a}$

\begin{tabular}{ll}
\hline Component or Property & \multicolumn{1}{c}{ Value } \\
\hline $\mathrm{NaOH}$ & $0.125 \mathrm{~mol} / \mathrm{L}(5.0 \mathrm{~g} / \mathrm{L})$ \\
$\mathrm{Na}_{2} \mathrm{CO}_{3}$ & $0.10 \mathrm{~mol} / \mathrm{L}(10.6 \mathrm{~g} / \mathrm{L})$ \\
$\mathrm{NaNO}_{3}$ & $0.06 \mathrm{~mol} / \mathrm{L}(5.1 \mathrm{~g} / \mathrm{L})$ \\
$\mathrm{NaCl}$ & $0.034 \mathrm{~mol} / \mathrm{L}(2.0 \mathrm{~g} / \mathrm{L})$ \\
$\mathrm{LiCl}$ & $0.025 \mathrm{~mol} / \mathrm{L}(1.06 \mathrm{~g} / \mathrm{L})$ \\
$\mathrm{NaAlO}_{2}$ & $0.012 \mathrm{~mol} / \mathrm{L}(0.98 \mathrm{~g} / \mathrm{L})$ \\
& \\
Solution pH & $\sim 13 \mathrm{standard} \mathrm{units}$ \\
Solution density & $\sim 1.07 \mathrm{~g} / \mathrm{L}$
\end{tabular}

\footnotetext{
$\overline{{ }^{a} \text { Based upon Table } 4.1 \text { in Arnold, et al. (1994), as amended (D. T. Bostick, personal communication, November 14, }}$ 1994).
} 
from research reactors; an estimated $48.5 \mathrm{~g}{ }^{99} \mathrm{Tc}$ will be generated per year, which may produce a peak concentration in the NGLLLW of approximately $0.5-1.0 \mathrm{mg} / \mathrm{L}$. The NGLLLW may be treated separately or it may be blended with small proportions (e.g., $\sim 20 \%$, by volume) of MVST waste before treatment. Thus, it is anticipated that ${ }^{99} \mathrm{Tc}$ may be present in NGLLLW and waste blends at concentrations of $\sim 0.5-5$ $\mathrm{mg} / \mathrm{L}$ (or activities of $\sim 8.5 \mathrm{E}-6$ to $8.5 \mathrm{E}-5 \mathrm{Ci} / \mathrm{L}$ ). The applicable discharge criterion for ${ }^{99} \mathrm{Tc}$ in aqueous effluent will be determined by regulatory permit; some reference criteria are given in Table 2 . The criterion in DOE Order 5400.5 corresponds to $1 \mathrm{E}-7 \mathrm{Ci} / \mathrm{L}$ (or $\sim 0.006 \mathrm{mg} / \mathrm{L}$ ). [The specific activity for ${ }^{99} \mathrm{Tc}$ is 0.017 $\mathrm{Ci} / \mathrm{g}]$.

Table 2. Reference criteria for ${ }^{99} \mathrm{Tc}$ in water

\begin{tabular}{|c|c|c|}
\hline $\begin{array}{l}\text { Criterion } \\
(\mathrm{pCi} / \mathrm{L})\end{array}$ & Significance & Reference or comment \\
\hline 600,000 & $\begin{array}{l}\text { Nuclear Regulatory } \\
\text { Commission (NRC) maximum } \\
\text { permissible value for release to } \\
\text { sanitary sewer (effective dose } \\
\text { equivalent of } 500 \mathrm{mrem} / \mathrm{y} \text { ) }\end{array}$ & 10 CFR, Chap. 1, Pt. 20, App. B \\
\hline 60,000 & $\begin{array}{l}\text { NRC maximum permissible } \\
\text { value for ingested water } \\
\text { (effective dose equivalent of } 50 \\
\mathrm{mrem} / \mathrm{y} \text { ) }\end{array}$ & 10 CFR, Chap. 1, Pt. 20, App. B \\
\hline 100,000 & $\begin{array}{l}\text { Ingested-water derived } \\
\text { concentration guide for }{ }^{99} \mathrm{Tc} \text { in } \\
\text { water (effective dose equivalent } \\
\text { of } 100 \mathrm{mrem} / \mathrm{y} \text { ) }\end{array}$ & DOE Order 5400.5 \\
\hline 3790 & $\begin{array}{l}\text { Recomputed limit for beta } \\
\text { activity in drinking water (to } \\
\text { yield an effective dose } \\
\text { equivalent of } 4 \mathrm{mrem} / \mathrm{y} \text {, } \\
\text { assuming }{ }^{99} \mathrm{Tc} \text { as sole beta } \\
\text { source) }\end{array}$ & $\begin{array}{l}\text { D. Davenport, Interoffice } \\
\text { Memorandum to L. Stinton, } \\
\text { Martin Marietta Energy } \\
\text { Systems, July } 1994\end{array}$ \\
\hline 900 & $\begin{array}{l}\text { Environmental Protection } \\
\text { Agency (EPA) Maximum } \\
\text { Contaminant Level for } \\
\text { manmade beta particle activity } \\
\text { in drinking water }\end{array}$ & $\begin{array}{l}\text { Value is apparently a } \\
\text { miscalculation for the effective } \\
\text { dose equivalent of } 4 \mathrm{mrem} / \mathrm{y}\end{array}$ \\
\hline $\begin{array}{l}\sim 4300 \\
\left(2.5 \times 10^{-9} \mathrm{~mol} / \mathrm{L}\right)\end{array}$ & $\begin{array}{l}\text { Solubility of electrodeposited } \\
\mathrm{Tc}(\mathrm{IV}) \text { oxides at } \mathrm{pH} \text { values } \\
3-10\end{array}$ & $\begin{array}{l}\text { R. E. Meyer, W. D. Arnold, and } \\
\text { F. I. Case, NUREG/CR-4865 } \\
\text { (ORNL-6374), July } 1987\end{array}$ \\
\hline 25 & $\begin{array}{l}\text { Proposed action level for } \\
\text { groundwater remediation }\end{array}$ & $\begin{array}{l}\text { Negotiations between Paducah } \\
\text { Gaseous Diffusion Plant and } \\
\text { Kentucky/EPA }\end{array}$ \\
\hline
\end{tabular}




\section{METHODS AND MATERIALS}

\subsection{SURROGATE SOLUTIONS}

Proposed flowsheets for the treatment of NGLLLW are presented in Arnold et al. (1994). Opportunities for treatment of technetium in the waste stream include the as-received waste $(\mathrm{pH} \sim 13)$, or after $\mathrm{pH}$ adjustment and co-precipitation of $\mathrm{Sr}$ at a $\mathrm{pH}$ value near 8-9. Surrogate for the as-generated waste water was prepared in accordance with the properties described in Table 1, using tap water as the solvent; analysis for a representative batch of filtered surrogate (designated as "solution 1A") is given in Table 3.

The $\mathrm{pH}$-adjusted surrogate was prepared according to instructions (D. T. Bostick, personal communication, January 1995): to a well-stirred 2-L aliquot of filtered Solution $1 \mathrm{~A}$, we added a solution containing $0.30 \mathrm{~g}$ $\mathrm{SrCl}_{2} \cdot 6 \mathrm{H}_{2} \mathrm{O}$ and $0.50 \mathrm{~g} \mathrm{Fe}_{2}\left(\mathrm{SO}_{4}\right)_{3} \cdot 9 \mathrm{H}_{2} \mathrm{O}$ in a minimal volume of water. The resulting slurry was allowed to $\mathrm{mix}$ for $\sim 1$-h, then Betz 1138 flocculating polymer was added at a final dosage of $\sim 2 \mathrm{mg} / \mathrm{L}$. Stirring was terminated and the slurry was allowed to flocculate and settle. The slurry was filtered through Whatman-40

filter paper medium. The final $\mathrm{pH}$ was adjusted using a solution of $\sim 20 \% \mathrm{H}_{2} \mathrm{SO}_{4}$. Small aliquots were collected for subsequent testing at selected intermediate $\mathrm{pH}$ values, whereas the bulk of the solution was adjusted to $\mathrm{pH} \sim 8-9$, then filtered to remove precipitate. The final filtered solution was designated "Solution $1 \mathrm{~B}^{\prime \prime}$ (cf Table 3 for analysis of one batch of surrogate preparation).

Technetium in alkaline oxic solution will be in the form of the pertechnetate anion, $\mathrm{TcO}_{4}^{-}$(Pourbaix, 1966). Filtered aliquots of simulated NGLLLW were supplemented with ${ }^{99} \mathrm{Tc}$ in the form of ammonium pertechnetate standard solution for subsequent testing.

\subsection{SORBENTS TESTED}

Sorbents selected for initial evaluation are briefly described below:

Dowex $^{\text {TM }}$ SBR (Dowex ${ }^{\text {TM }}$ 1-X8, chloride form, 50/100 mesh; lot \# 23104). This material is a Type 1, tertiary amine (-NR $\mathrm{N}_{3}$, where $\mathrm{R}=\mathrm{CH}_{3}$ ), strongly basic polystyrene gel anion exchange resin. The as-tested material contained $\sim 18 \%$ moisture (as estimated by weight loss upon drying at $\sim 100^{\circ} \mathrm{C}$ ). Vendor literature suggests a total ion exchange capacity of $\sim 3.2 \mathrm{eq} / \mathrm{kg}$ (dry), and a moisture content of $\sim 43-48 \%$.

Dowex $^{\mathrm{TM}}$ 2-X8 (chloride form, 20/50 mesh; lot \# M1566). This material is a Type 2, tertiary amine (-NR $\mathrm{R}^{\prime}$, where $\mathrm{R}=\mathrm{CH}_{3}$ and $\mathrm{R}^{\prime}=\mathrm{CH}_{2} \mathrm{CH}_{2} \mathrm{OH}$ ), strongly basic polystyrene gel anion exchange resin. The as-received material contained $\sim 34 \%$ moisture (as estimated by weight loss upon drying at $\sim 100{ }^{\circ} \mathrm{C}$ ). Vendor literature suggests a total ion exchange capacity of $\sim 3.2 \mathrm{eq} / \mathrm{kg}$ (dry), and a moisture content of $\sim 38-45 \%$.

Bio-Rad ${ }^{\mathrm{TM}}$ AG 1-X8 (hydroxide form, $20 / 50$ mesh; lot \# 42001A). The as-tested material contained 58\% moisture (as estimated by weight loss upon drying at $\sim 100{ }^{\circ} \mathrm{C}$ ). The material is an analytical grade equivalent to Dowex ${ }^{\mathrm{TM}} 1-\mathrm{X8}$.

Reillex ${ }^{\mathrm{TM}} \mathrm{HP}$ (30/60 mesh, lot \# 88-1, Reilley Industries, Indianapolis IN). The material is a macroporous co-polymer of 4-vinylpyridine and divinylbenzene (CAS Registry Number 9017-40-7). The as-tested material contained $\sim 31 \%$ moisture (as estimated by weight loss upon drying at $\sim 100{ }^{\circ} \mathrm{C}$ ). Vendor literature suggests a total ion exchange capacity of $\sim 5.5 \mathrm{eq} / \mathrm{kg}$ (dry). 
, 
Table 3. Analysis of Surrogate Wastewater Preparations

\begin{tabular}{lcc}
\hline \multicolumn{1}{c}{ Analysis } & $\begin{array}{c}\text { Solution 1A } \\
\text { (AnaLIS 950310-029) }\end{array}$ & $\begin{array}{c}\text { Solution 1B } \\
\text { (AnaLIS 950127-076) }\end{array}$ \\
$\mathrm{pH}(\mathrm{std}$. unit) & 13.5 & 8.9 \\
$\mathrm{Eh}(\mathrm{mV}, \mathrm{vs} \mathrm{NHE})^{\mathrm{a}}$ & 150 & 373 \\
$\mathrm{Al}(\mathrm{mg} / \mathrm{L})$ & 320 & $<2$ \\
$\mathrm{Ba}(\mathrm{mg} / \mathrm{L})$ & 0.016 & $<0.10$ \\
$\mathrm{Ca}(\mathrm{mg} / \mathrm{L})$ & 0.053 & $<0.80$ \\
$\mathrm{Fe}(\mathrm{mg} / \mathrm{L})$ & $<0.50$ & $<0.50$ \\
$\mathrm{Mg}(\mathrm{mg} / \mathrm{L})$ & 0.61 & $<0.30$ \\
$\mathrm{Li}(\mathrm{mg} / \mathrm{L})$ & 100 & 96 \\
$\mathrm{Na}(\mathrm{mg} / \mathrm{L})$ & 9700 & 9200 \\
$\mathrm{Sr}(\mathrm{mg} / \mathrm{L})$ & 0.97 & $<0.04$ \\
$\mathrm{Zn}(\mathrm{mg} / \mathrm{L})$ & 0.076 & 0.26 \\
\hline
\end{tabular}

a Electrode redox potential relative to Standard Hydrogen Electrode

Reillex ${ }^{\mathrm{TM}}$ HPQ (chloride form, 30/60 mesh, lot \# 90928AC; Reilley Industries, Indianapolis IN). The material is a co-polymer of partially quaternized 4-vinylpyridine and divinylbenzene (CAS Registry Number $125200-80-8$ ). The exchange groups are $\sim 70 \%$ strong-base (methyl pyridinium) and $\sim 30 \%$ weak-base (pyridinium) sites. The as-tested material contained $\sim 58 \%$ moisture (as estimated by weight loss upon drying at $\sim 100^{\circ} \mathrm{C}$ ). Vendor literature suggests a total ion exchange capacity of $\sim 4.6 \mathrm{eq} / \mathrm{kg}$ (dry).

Rohm \& Haas Duolite ${ }^{\mathrm{R}}$ GT-73 (lot \# 890394-8). The functionality of this resin is provided mainly by the thiol (-SH) group, with minor contribution by sulfonic acid groups; the product is a cation exchange resin, with selectivity in the sequence: $\mathrm{Hg}>\mathrm{Ag}>\mathrm{Cu}>\mathrm{Pb}>\mathrm{Cd}>\mathrm{Ni}>\mathrm{Co}>\mathrm{Fe}>\mathrm{Ca}>\mathrm{Na}$. The as-received material contained $\sim 66 \%$ moisture (as estimated by weight loss upon drying at $\sim 100^{\circ} \mathrm{C}$ ).

Bronze wool (Elephant brand). This material was determined to be copper metal (with trace silicon impurity), and had a median strand diameter $42.7 \pm 3.8 \mu \mathrm{m}$.

Steel wool. The material tested was removed from an Eastman Kodak chemical recovery canister (catalog no. 173-4953; lot \# 17934). The canister contains $~ 3.4 \mathrm{~kg}$ steel in a nominal volume of $\sim 5.5$ gal $(\sim 20-\mathrm{L})$, or a nominal packing density for the steel of $\sim 0.17 \mathrm{~g} / \mathrm{cm}^{3}$. The iron metal strands (ribbon) had a median diameter $93 \pm 36 \mu \mathrm{m}$. 


\subsection{EQUILIBRIUM ISOTHERM TESTING AND LIQUID SCINTILLATION TESTING}

Techniques and instrumentation used are described in Bostick et al. (1995). Briefly, an accurately measured mass of sorbent and a measured aliquot of solution are equilibrated for $24-\mathrm{h}$ by shaking on a Burrell wristaction shaker. Measured aliquots of filtered aqueous phase are dispensed into individual 20-mL liquid scintillation vials, and $10-\mathrm{mL}$ of nonhazardous Eco-Lite ${ }^{\mathrm{TM}}$ scintillation cocktail is added. Technetium-99 activity is quantitated by placing the vials into a calibrated alpha-beta scintillation counter (Packard 2550 TR/AB). With this instrumentation and the defined spectral energy window, detection of ${ }^{99} \mathrm{Tc}$ is $\sim 93 \%$ efficient. Analytical data (net counts $/ \mathrm{min} / \mathrm{mL}$, or CPM/mL) is converted to technetium activity by the approximation that disintegrations $/ \mathrm{min}(\mathrm{DPM})=1.1 \mathrm{CPM}$, and Tc concentration is estimated by the specific activity $\left(37,800 \mathrm{DPM}=630 \mathrm{~Bq}=1 \mu \mathrm{g}{ }^{99} \mathrm{Tc}\right)$.

\subsection{PACKED-COLUMN EVALUATE BREAKTHROUGH STUDIES}

Test solution was metered through the columns with use of a calibrated WIZ (Isco, Inc., Lincoln NE) peristaltic pump. Discrete effluent samples were collected with a Foxy 200 (Isco, Inc., Lincoln NE) programmable fraction collector, and aliquots were counted off-line by liquid scintillation. 


\section{RESULTS AND DISCUSSION}

\subsection{EQULIBRIUM SORPTION ISOTHERMS}

In Figure 1, we examine the effectiveness of several candidate sorption media for removal of ${ }^{99} \mathrm{Tc}(\sim 0.2$ $\mathrm{mg} / \mathrm{L}$ ) from surrogate NGLLLW, adjusted to various $\mathrm{pH}$ values and filtered. For the data in Table 1, a single sorption dosage was used $(0.1 \mathrm{~g}$ as-received sorbent in $10 \mathrm{~mL}$ solution); single point distribution coefficients were computed for the organic resin sorbents according to the simple linear sorption isotherm model:

$$
S=K_{d} C,
$$

where

$$
\begin{aligned}
& S=\text { mass sorbed at equilibrium per mass of sorbent, } \\
& K_{d}=\text { distribution coefficient }(\mathrm{mL} / \mathrm{g}) \\
& C=\text { sorbate concentration in solution at equilibrium }(\mathrm{g} / \mathrm{mL}) .
\end{aligned}
$$

As shown in Figure 1, relatively little effect of solution $\mathrm{pH}$ on sorption of ${ }^{99} \mathrm{Tc}$ by organic resins was noted over the range $\mathrm{pH} \sim 9-13$. Of the organic resins tested, Dowex ${ }^{\mathrm{TM}} 1-\mathrm{X} 8$ and Reillex ${ }^{\mathrm{TM}} \mathrm{HPQ}$ appeared to be the most effective, and performed nearly equivalently (median values for $K_{d} \sim 2,000 \mathrm{~mL} / \mathrm{g}$, for the as-tested resin).

In contrast to the behavior of the organic resin media, removal of ${ }^{99} \mathrm{Tc}$ by steel wool was notably $\mathrm{pH}$ dependent, with little or no removal at $\mathrm{pH} \geq 12$ (corresponding to the Eh-pH domain for passivation against corrosion of iron metal; see Pourbaix 1966), and near-complete removal of soluble Tc at near-neutrality. Data reported by Bostick et al. (1995) for the treatment of near-neutral Tc-contaminated process and ground water suggests that significant reduction of soluble $\mathrm{Tc}(\mathrm{VII})$ and binding of $\mathrm{Tc}(\mathrm{IV})$ oxyhydroxide product occurs concurrently with corrosion (oxidation) of the iron substrate, and that incorporation of $\mathrm{Tc}(\mathrm{IV})$ in the iron oxyhydroxide surface layer may help stabilize Tc(IV) against subsequent reoxidation by dissolved air. High concentrations of nitrate ion appears to accelerate both the corrosion of the base iron substrate and the concurrent removal of soluble ${ }^{99} \mathrm{Tc}$. It has been noted that "..pertechnetates, even in very low concentrations, have remarkable inhibitive properties for the corrosion of electrolytic iron, soft steel, and cast iron in contact with water or neutral, alkaline, or slightly acid solutions of chlorides or other salts" (Pourbaix 1966); perhaps the corrosive nature of nitrate salts allows the continued reduction of the technetium by the iron substrate.

In concurrent investigations, we examined several sorbents for the removal of dissolved mercury in simulated wastewater from the treatment of crushed fluorescent lamps (Beck et al., 1995); materials which were relatively effective for sorption of mercury from solution, but which did not perform effectively for removal of technetium in this series of tests, included Duolite resin and degreased copper wool. Although the Duolite resin is a cation-exchanger, it was thought that the associated thiol functionality could perhaps bind Tc (which is known to form insoluble sulfide complexes). The poor performance by copper wool was somewhat unexpected, since zinc metal has been shown to reduce pertechnetate ion (Mushtaq, 1993), and copper metal had been proposed as a candidate reagent for addition to backfill material to decrease the diffusivity of technetium, uranium and transuranics in anoxic groundwater (Albinsson, et al., 1991). 


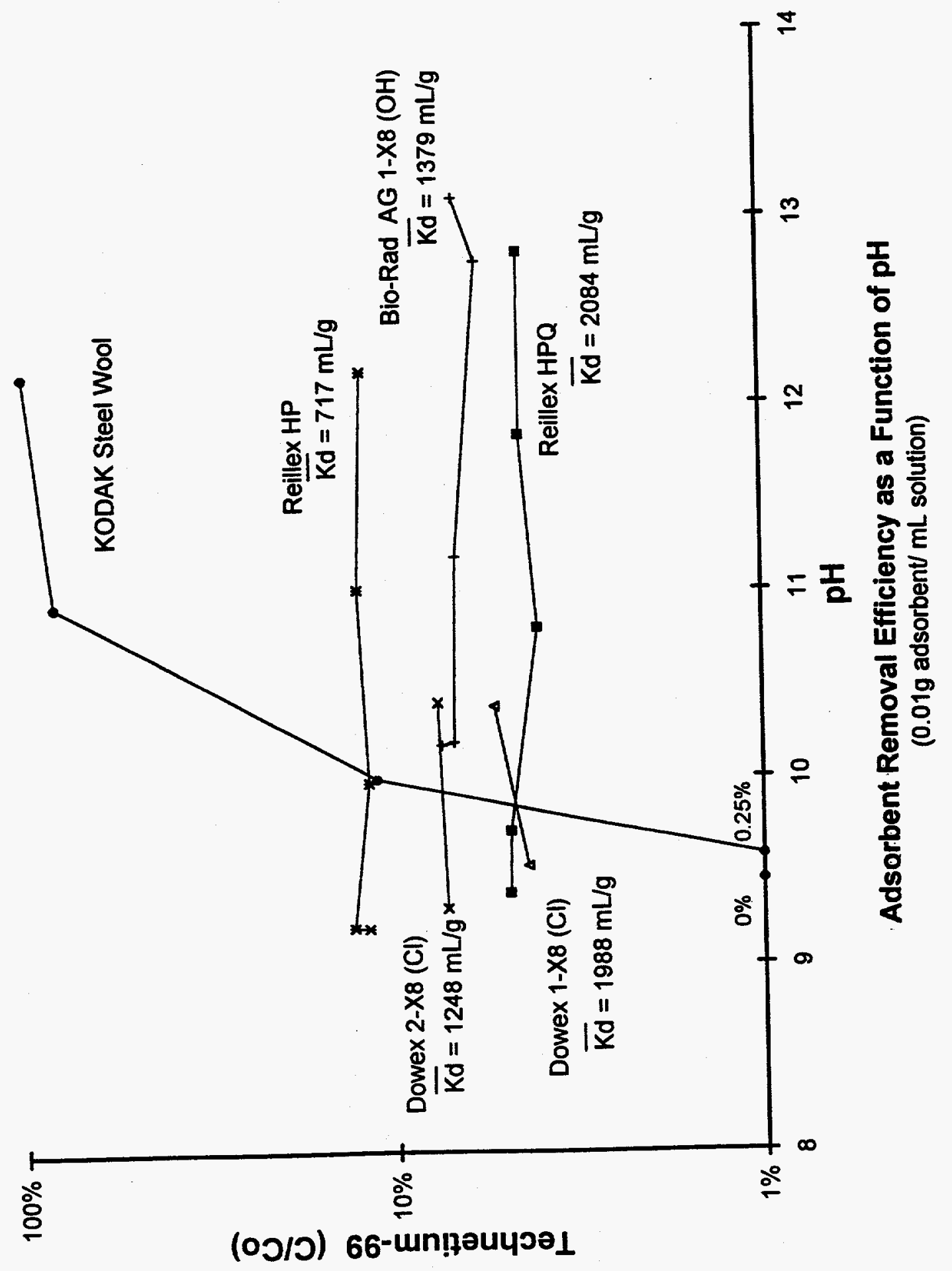

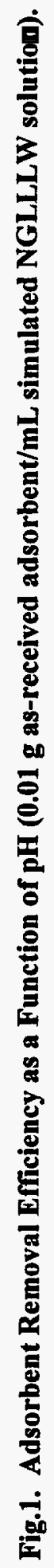


Some of the more effective organic resins were tested over a range of sorbent dosages to allow a more precise estimate of their distribution coefficients for Tc (via regression analysis for the slope, S/C, from equation (1)). Figures 2 and 3 illustrates the data for "Solution 1A" and Solution 1B", respectively (cf Table 3 ), fitted to the linear isotherm model . Estimates for $K_{d}$ from this data are summarized in Table 4 . These data are in general agreement with the single-dosage values presented in Figure 1, but suggest that sorption of Tc is somewhat more efficient in the near-neutral solution.

Table 4. Estimate of Distribution Coefficient $\left(K_{d}\right)$ for ${ }^{99} \mathrm{Tc}$ in Simulated NGLLLW by Selected Resins.

\begin{tabular}{|c|c|c|}
\hline Material & $\begin{array}{l}\text { "Solution } 1 \mathrm{~A}^{\prime \prime} \\
\left(K_{d}, \mathrm{~mL} / \mathrm{g} \text { resin) }\right.\end{array}$ & $\begin{array}{l}\text { "Solution 1B"^ } \\
\left(K_{d}, \mathrm{~mL} / \mathrm{g}, \text { resin) }\right.\end{array}$ \\
\hline Dowex 1-X8, chloride form & $\begin{array}{l}1,850 \text { (as-tested) } \\
\sim 2,230 \text { (dry) }\end{array}$ & $\begin{array}{l}\text { 2,370(as-tested) } \\
\sim 2,850 \text { (dry) }\end{array}$ \\
\hline Dowex 2-X8, chloride form & $\begin{array}{l}\text { 1,280(as-tested) } \\
\sim 1,940 \text { (dry) }\end{array}$ & $\begin{array}{l}1,390 \text { (as-tested) } \\
\sim 2,100 \text { (dry) }\end{array}$ \\
\hline Reillex HPQ & $\begin{array}{l}917 / 1010 \text { (as tested) } \\
\sim 2,200 \text { (dry) }\end{array}$ & $\begin{array}{l}\text { 2108(as-tested) } \\
\sim 5,020 \text { (dry) }\end{array}$ \\
\hline Reillex HP & $\begin{array}{l}577 \text { (as-tested) } \\
\sim 840 \text { (dry) }\end{array}$ & $\begin{array}{l}902 \text { (as-tested) } \\
\sim 1,300 \text { (dry) }\end{array}$ \\
\hline BioRad AG 1-X8, hydroxide form & $\begin{array}{l}1,070 \text { (as-tested) } \\
\sim 2,500 \text { (dry) }\end{array}$ & $\begin{array}{l}1,417 \text { (as-tested) } \\
\sim 3,400 \text { (dry) }\end{array}$ \\
\hline
\end{tabular}

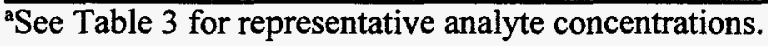

\subsection{PACKED COLUMN BREAKTHROUGH STUDIES: DOWEX ${ }^{\mathrm{TM}}$ 1-X8}

For many decades, use of strongly basic anion-exchange resin, such as Dowex ${ }^{\mathrm{TM}} 1-\mathrm{X} 8$, has been the benchmark technology for separating technetium from nuclear waste solutions (Huffman, et al., 1956; Roberts, et al., 1962; Kiseleva, et al., 1971; Deacon and Greiner, 1982). Our equilibrium sorption isotherm data (Section 4.2) indicates that this material is a good candidate for use with NGLLLW solution.

Dowex ${ }^{\mathrm{TM}} 1-\mathrm{X} 8$, chloride form, was slurry-packed into a $0.7-\mathrm{cm}$ (internal diameter) Kontes FlexColumn to yield a packed bed volume of $7.50 \mathrm{~cm}^{3}$; the dry-weight equivalent of the resin in the packed bed was $\sim 2.84$ g. Simulated NGLLLW, treated for co-precipitation of Sr, adjusted to $\mathrm{pH} 8$ and filtered, was used as the column feed. The amount of ${ }^{99} \mathrm{Tc}$ added to the surrogate solution feed was increased several times during the duration of the test, in order to achieve detectable breakthrough. The initial feed contained $\sim 0.8 \mathrm{mg} / \mathrm{L}$ ${ }^{99} \mathrm{Tc}$, and the final feed was increased to $\sim 23 \mathrm{mg} / \mathrm{L}{ }^{99} \mathrm{Tc}$. The flow rate was $1.3 \mathrm{~mL} / \mathrm{min}$, equivalent to $\sim 0.83$ $\mathrm{gal} / \mathrm{min} / \mathrm{ft}^{2}$ (cross-sectional area), and the nominal reactive zone residence time was $\sim 5.8 \mathrm{~min}$. Data are shown in Figure 4. Little or no breakthrough of ${ }^{99} \mathrm{Tc}$ was noted until the column had loaded $>8 \mathrm{mg}{ }^{99} \mathrm{Tc}$ per $\mathrm{cm}^{3}$ of resin volume; this column loading at incipient breakthrough corresponds to $\sim 7 \%$ of the nominal resin ion exchange capacity. Assuming an influent containing $\sim 3 \mathrm{mg} / \mathrm{L}{ }^{99} \mathrm{Tc}$, a cubic foot of wet resin could treat $>20,000$ gal of waste before appreciable breakthrough. 


\section{Sorption Isotherm for Technetium-99 \\ (surrogate NGLLLW wisoin A)}

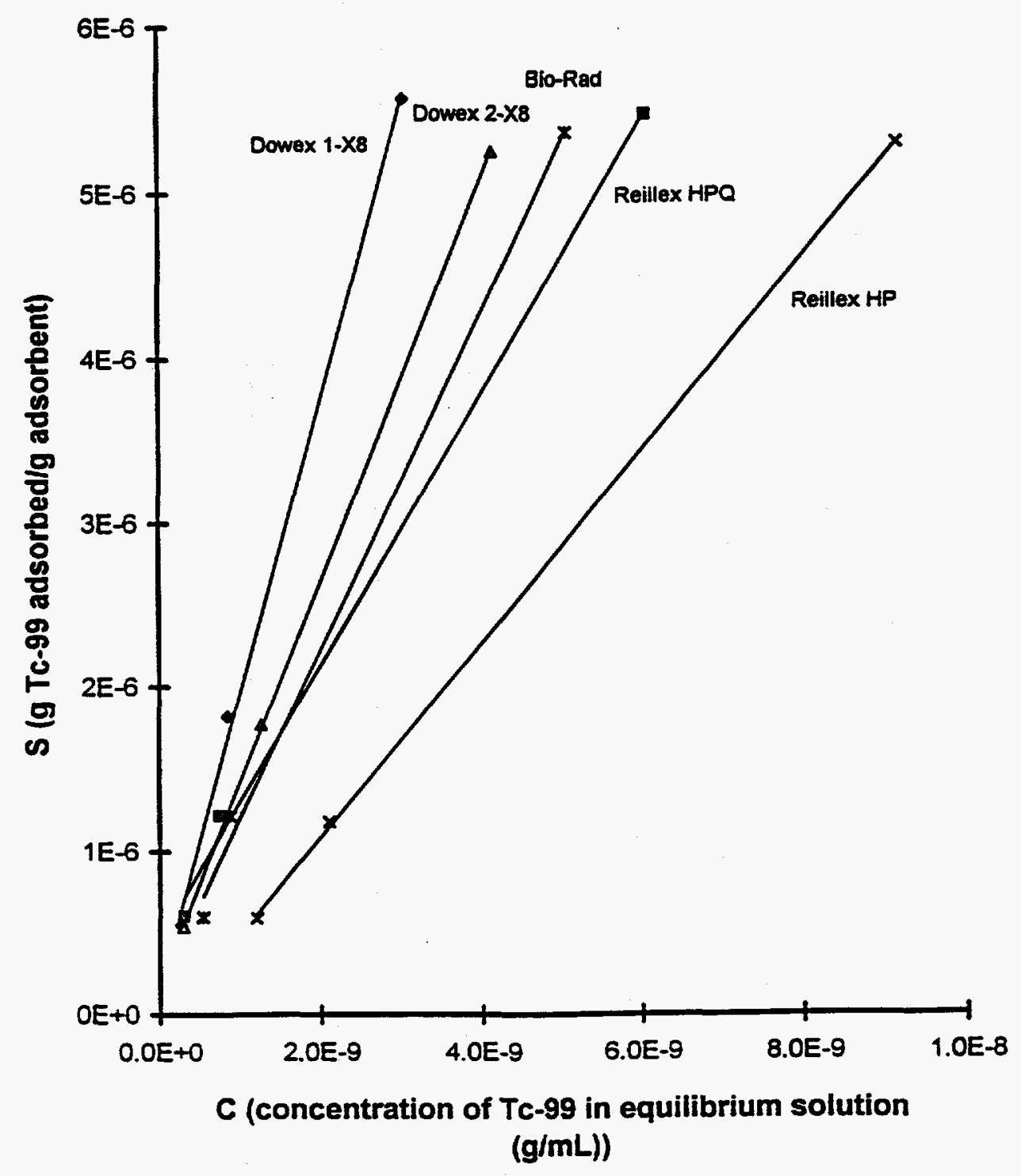

K-1006: Materials and Chemistry Laboratory

Fig.2. Linear sorption isotherm data for removal of soluble ${ }^{99} \mathrm{Tc}$ in Simulated NGLLLW "Solution A" by selected sorbents. 


\section{Sorption Isotherm for Technetium-99}

(surrogate NGLLLW w/soin B)

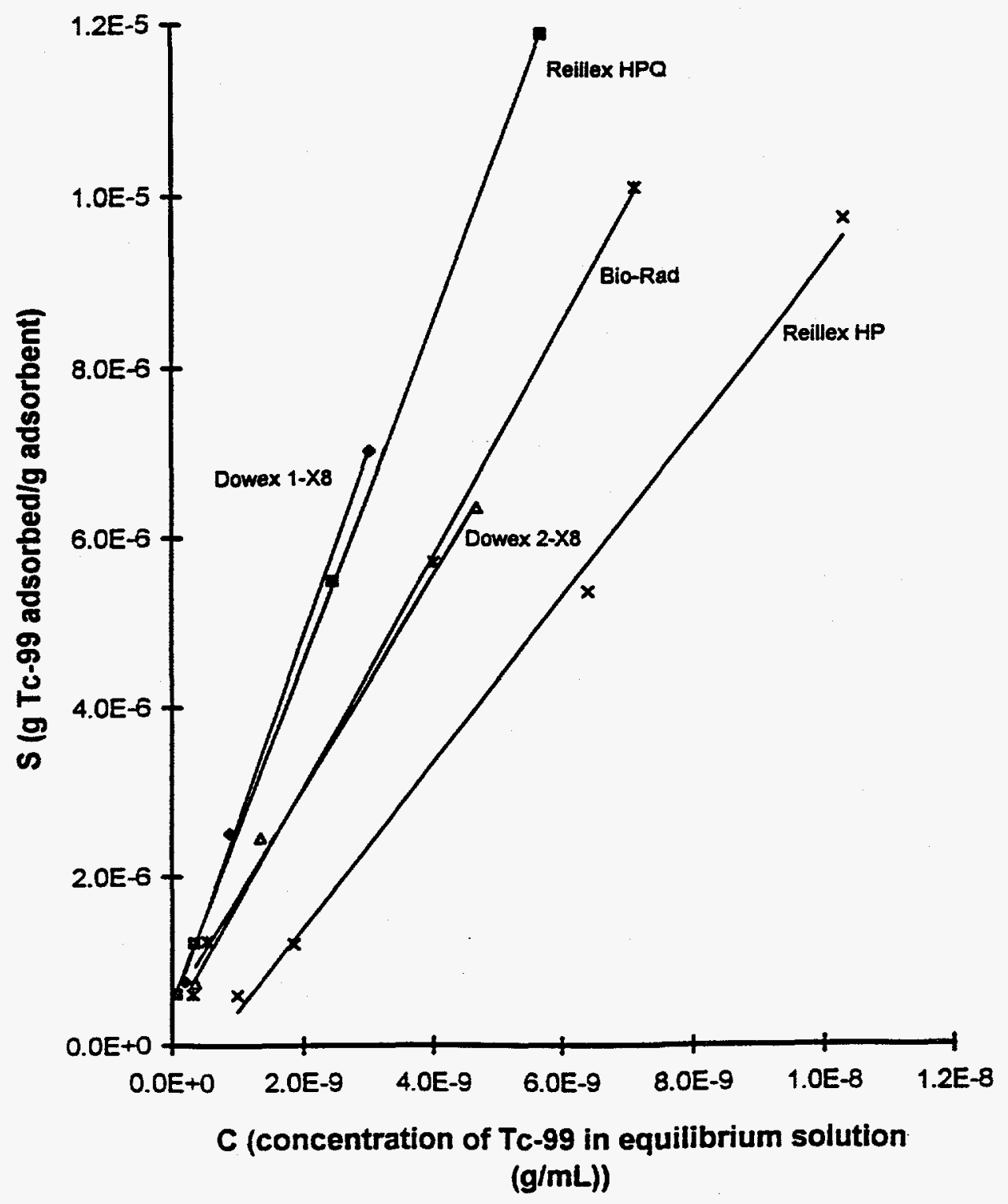

K-1006: Materials and Chemistry Laboratory

Fig.3. Linear sorption data for removal of soluble ${ }^{99} \mathrm{Tc}$ in Simulated NGLLLW "Solution B" by selected sorbents. 


\section{Breakthrough Test for Tc-99}

(using Dowex 1-X8 resin in surrogate ORNL newly generated low-level liquid waste)

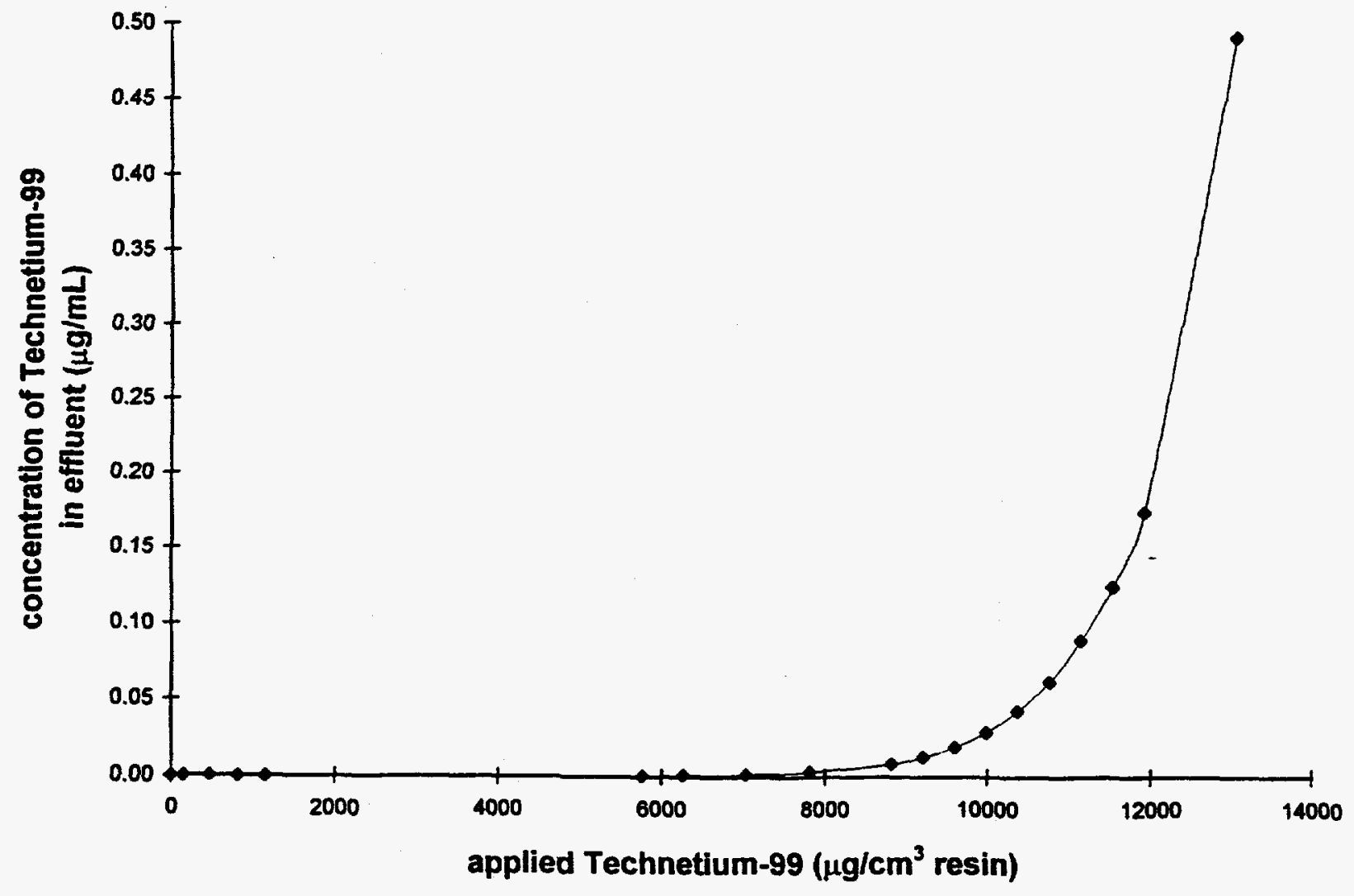

K-1006 Materials and Chemistry Laboratory

Fig.4. Breakthrough of ${ }^{99}$ Tc from Dowex ${ }^{\text {TM }}$ 1-x-8 Resin Under Dynamic Flow (Influent : Simulated NGLLLW “Solution B"). [ $\sim 0.83$ GPM/ft2 (cross-secitional area); nominal column residence time -5.8 min.] 


\subsection{PACKED COLUMN BREAKTHROUGH STUDIES: STEEL WOOL}

Del Cul and Bostick (1995) have shown that degreased iron filings (Fisher reagent I-57) were effective for the removal of ${ }^{99} \mathrm{Tc}$ in simulated heavy metals sludge filtrate (containing $\sim 1.5 \mathrm{~mol} / \mathrm{L}$ nitrate ion at $\mathrm{pH} \sim 8.5$ ) under dynamic flow conditions; in this high-nitrate brine, iron was more effective in removing ${ }^{99} \mathrm{Tc}$ than was either Reillex HPQ or Dowex ${ }^{\mathrm{TM}}$ 1-X8 (see Figure 5). In equilibrium sorption testing, Bostick, et al. (1995) demonstrated that Kodak steel wool, and several other iron products, were as effective for Tc-reduction as the Fisher I-57 product. Beck, et al. (1995) have shown that the Kodak steel wool reagent functioned efficiently for the removal of mercury from simulated wastewater under dynamic flow conditions (Figure 6). In the latter application, mercuric chloride solution was fed by upflow to a packed column containing steel wool $\left(\sim 0.93 \mathrm{~g} / \mathrm{cm}^{3}\right)$ at a rate equivalent to $\sim 0.14 \mathrm{gal} / \mathrm{min} / \mathrm{ft}^{2}$ (cross-sectional area), nominal residence time $\sim 11$ min.; redox activity was evidenced by the formation of metallic mercury within the column and iron salts in the column effluent. As observed through the translucent tubing leading to the fraction collector, the effluent immediately downstream of the column had a greenish tint, suggestive of ferrous iron, and further downstream the effluent became orange-brown, suggestive of ferric hydroxide.

As shown in Figure 1, Kodak steel wool appears to be an effective (and economic) candidate for removal of soluble ${ }^{99} \mathrm{Tc}$. This product is marketed commercially for the recovery of silver from spent photographic developer solution. We prepared a packed-bed column by placing $6.52 \mathrm{~g}$ Kodak steel wool into an $11-\mathrm{mm}$ (internal diameter) glass tube, with glass wool packed before and after the steel wool plug, yielding an active zone of $\sim 15.4 \mathrm{~cm}^{3}$ steel, or an effective packing density of $\sim 0.4 \mathrm{~g} / \mathrm{cm}^{3}$ (about twice the packing density of the Kodak canister). Assuming a typical value for the density of steel $\left(\sim 7.6 \mathrm{~g} / \mathrm{cm}^{3}\right)$, the initial amount of steel was only $\sim 6 \%$ of the nominal reactive zone volume (i.e., the initial reaction zone contained $\sim 94$ $\%$ 'void volume'). The column influent was simulated NGLLLW, adjusted to $\mathrm{pH} 8$ and filtered, supplimented to contain $\sim 0.11 \mathrm{mg} / \mathrm{L}^{99} \mathrm{Tc}$. The flow rate was $1.75 \mathrm{~mL} / \mathrm{min}$ (equivalent to $\sim 0.49 \mathrm{gal} / \mathrm{min} / \mathrm{ft}^{2}$ (cross-sectional area), and the nominal column residence time was $\sim 8.8 \mathrm{~min}$.

Figure 7 illustrates the data for the activity of ${ }^{99} \mathrm{Tc}$ in the effluent from the steel wool column. In contrast to the performance of the Dowex ${ }^{\mathrm{TM}} 1-\mathrm{X} 8$ column, which had little or no 'bleed' of ${ }^{99} \mathrm{Tc}$ prior to a distinct breakthrough (cf Figure 4), the steel wool column yielded effluents containing a continuous $\sim 1-3 \%$ 'bleed', without a distinct 'breakthrough' during $\sim 1200$ bed volumes, at which time flowrate became erratic due to column plugging (presumably, due to rust formation). 


\section{Technetium-99 Removal}

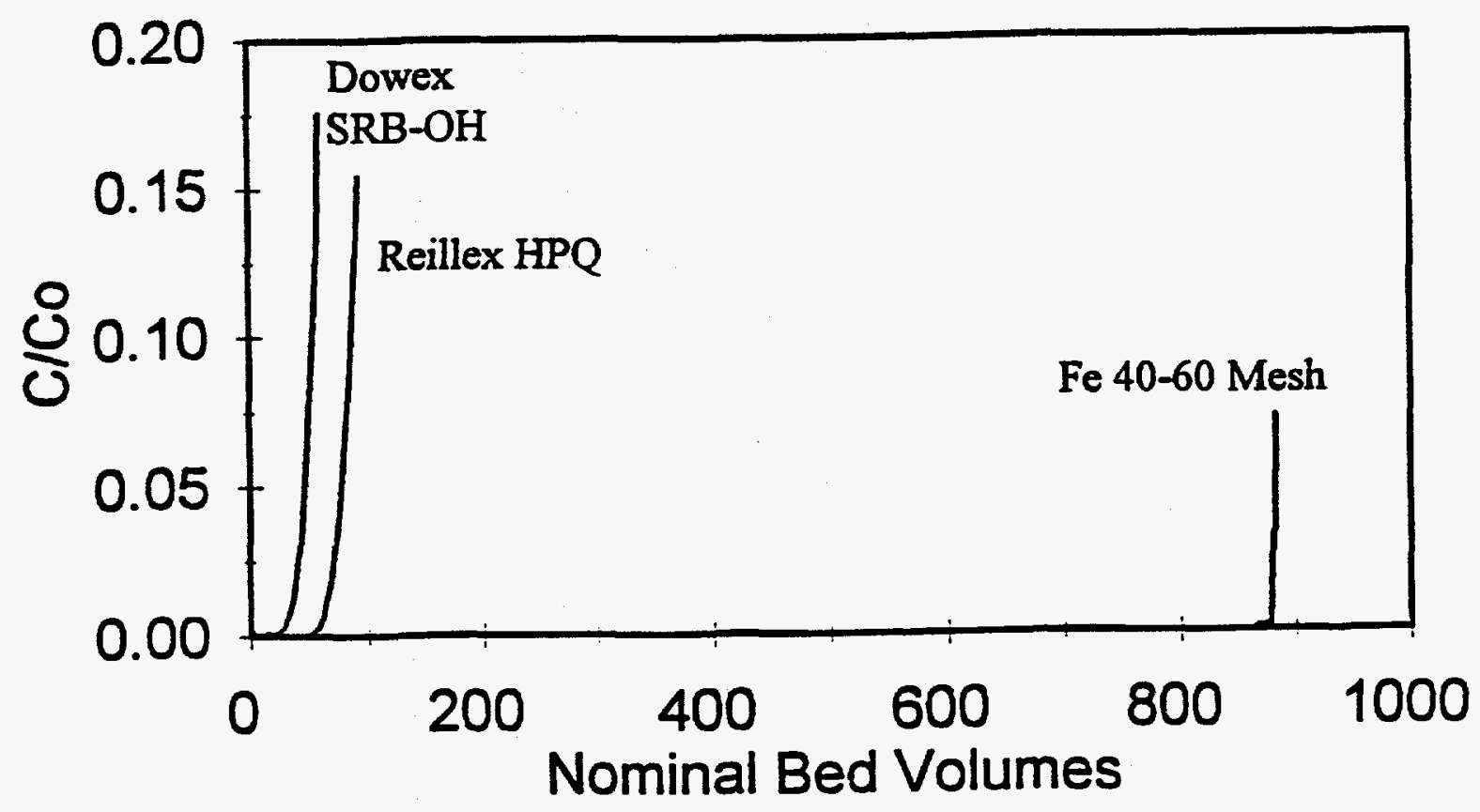

Fig.5. Breakthrough of ${ }^{99}$ Tc from Packed-Bed Columns Under Dynamic Flow: Dowex ${ }^{\mathrm{TM}}$ 1-X-8, Reillex $^{\text {TM }}$ HPQ, and Fisher I-57 Iron Filings Under Dynamic Flow (Influent: Simulated Portsmouth Gaseous Dioffusion Plant Heavy Metals Filtrate). From Del Cul and Bostick (1995). 


\section{Breakthrough Test for Mercury}

(using steel wool in simulated wastewater)

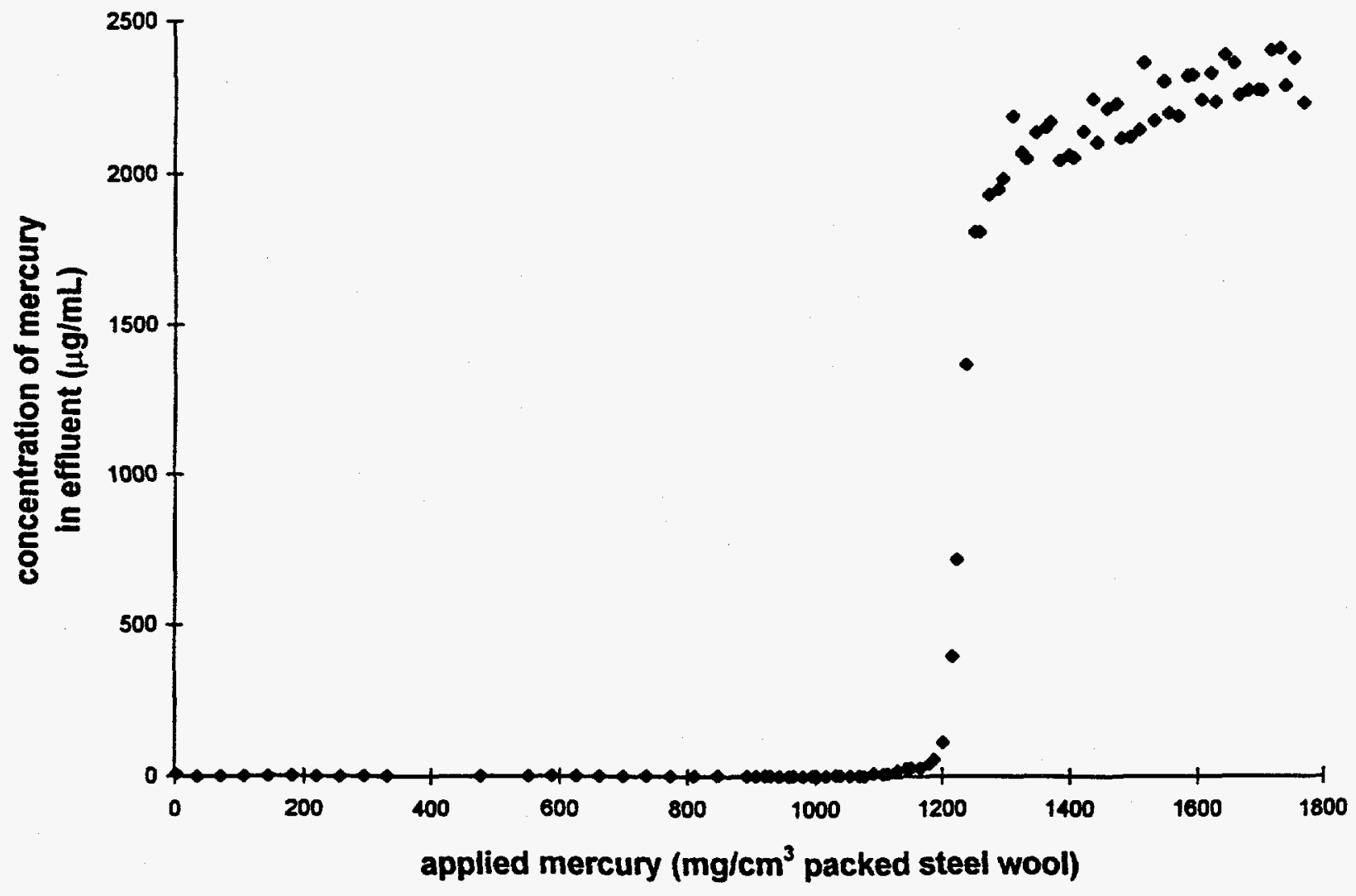

K-1006 Materials and Chemistry Laboratory

Fig.6. Breakthrough of Mercury from Kodak Steel Wool Under Dynamic Flow (Influent: $\mathrm{HgCl}_{2}$ solution, traced with ${ }^{203} \mathrm{Hg}$ ). $\left[\sim 0.15 \mathrm{GPM} / \mathrm{ft}^{2}\right.$ (cross-sectional area); nominal column residence time -12 min.] 


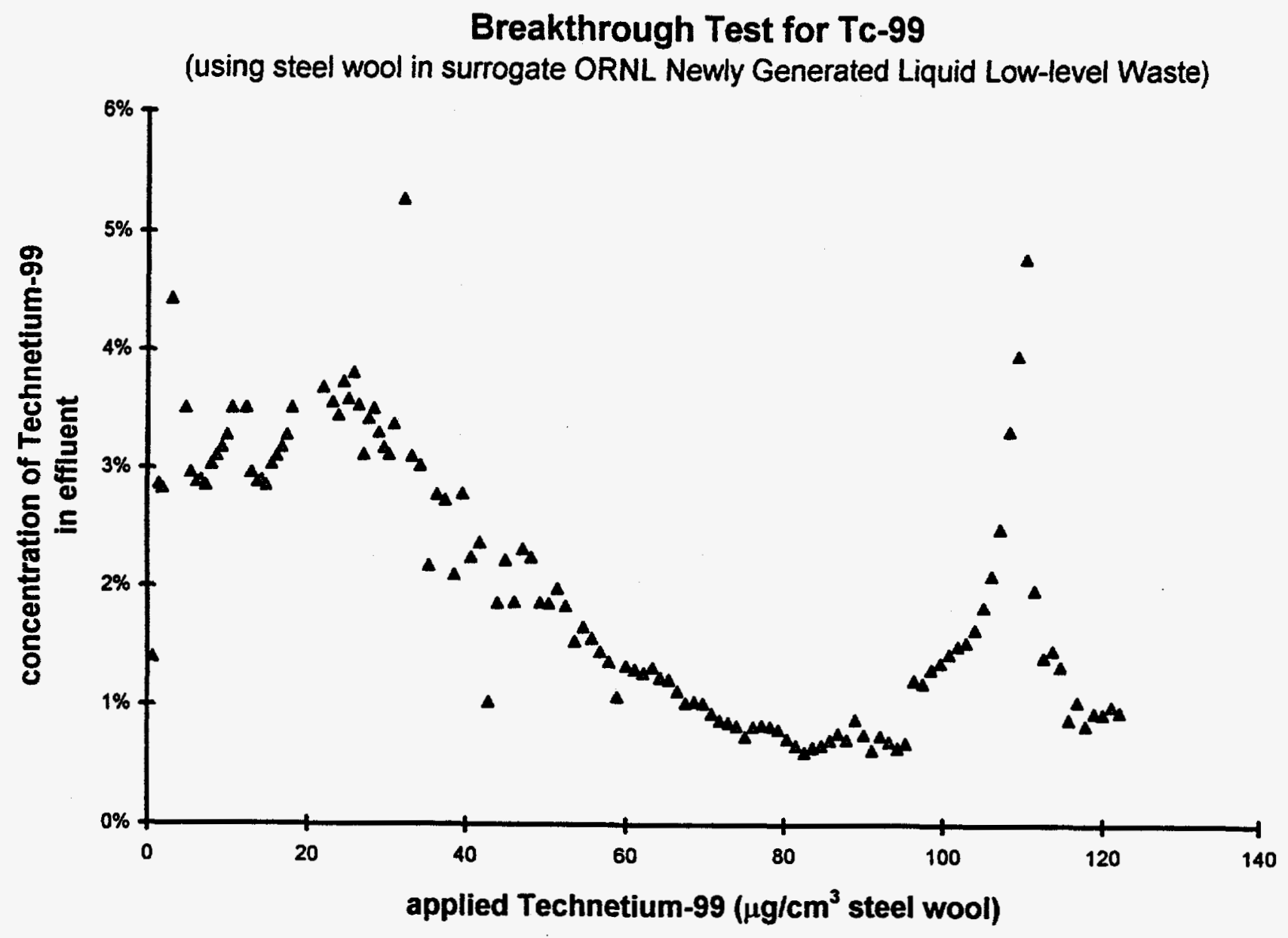

K-1006 Materials and Chemistry Laboratory

Fig.7. Dynamic Flow Elution for ${ }^{99}$ Tc from Kodak Steel Wool (Influent: Simulated NGLLW “Solution B"). [ -0.45 GPM/ft ${ }^{2}$ (cross-sectional area); nominal column residence time $\sim 9.2 \mathrm{~min}$.] 


\section{CONCLUSIONS \& RECOMMENDATIONS}

Use of Type 1 strongly-basic anion exchange medium, such as Dowex ${ }^{\mathrm{TM}} 1-\mathrm{X} 8$, is an established technology for removal of pertechnetate ion from aqueous waste, and it is likely to be the technology of choice for removal of soluble ${ }^{99} \mathrm{Tc}$ from the NGLLLW. The chief limitation on the use of this type of sorptive medium is the interference by high concentrations of nitrate ion; fortunately, the NGLLLW has relatively modest concentrations of this interferant (see Table 1).

For Dowex ${ }^{\mathrm{TM}} 1-\mathrm{X} 8$ resin in media at constant ionic strength, the sorptive distribution coefficient $\left(K_{d}\right)$ for pertechnetate decreases in the order hydroxide $>$ chloride $>$ nitrate $>$ perchlorate, and selectivity decreases in the order pertechnetate $>$ perchlorate $>$ nitrate $>$ chloride $>$ hydroxide (Kawasaki, et al., 1993). Thus, for this type of medium, high concentrations of nitrate ion decrease the effective sorption of pertechnetate for a given mass of resin sorbent, and bound pertechnetate can only be displaced from the resin by high concentrations of strong ligand, such as perchloric or nitric acid (Momoshima, et al., 1993; Kawasaki, et al., 1993). Although the use of concentrated strongly oxidative acid solutions for column elution and recovery of trace ${ }^{99} \mathrm{Tc}$ may be useful on a microanalysis scale, these chemicals present serious safety concerns for large-scale application. Thus, industrial-scale regeneration of spent Type 1 strongly-basic anion exchange resin containing ${ }^{99} \mathrm{Tc}$ appears to be impractical, and the resin medium must be discarded after its exchange capacity has become saturated.

Relative to Type 1 strongly-basic anion exchange resin, polyvinylpyridine resins are not as adversely affected by high nitrate ion concentration, and show enhanced chemical, thermal, and radiation stability (Gangwer, et al., 1977). If the NGLLLW is to be blended with strongly alkaline MVST legacy waste containing much higher concentrations of nitrate ion $(\sim 5.4 \mathrm{~mol} / \mathrm{L}$ in the concentrated supernate; Arnold, et al., 1995), then a resin such as Reillex ${ }^{\mathrm{TM}} \mathrm{HPQ}$, may be preferred [see Schroeder and coworkers (1993-1995) for a discussion on the use of Reillex ${ }^{\mathrm{IM}} \mathrm{HPQ}$ resin in high-nitrate alkaline tank waste from the Hanford Operations site]. Recent work suggests that bound pertechnetate can be readily stripped from Reillex ${ }^{\mathrm{TM}} \mathrm{HPQ}$ resin with use of a reductive solution (containing stannous chloride), which allows the resin to be reused (Schroeder, et al., 1995). The possibility of regeneration/reuse of resin could shift the life-cycle processing costs in favor of the use of this type of sorptive medium. The desorbed reduced Tc concentrate must be conditioned to prevent accidental release back into the environment.

Iron metal could remain a candidate for removal of ${ }^{99} \mathrm{Tc}$ from high-nitrate waste, but would require prior neutralization of the waste water (Del Cul and Bostick, 1995). Although use of iron is an economical, innovative treatment technology, it may be more difficult to accurately predict its sorptive capacity or functional 'lifetime' (before rusting of substrate causes flow-restriction).

Spent sorptive media must be conditioned for disposal. Recently, McGinnes and Dyer (1992) reviewed disposal options for ${ }^{99} \mathrm{Tc}$-laden ion exchange resins, including incineration, wet oxidation, and compaction, but concluded that encapsulation is the simplest method.

We have shown that durable waste forms can be prepared by imbedding the resin in special grout-blends or in polymer (such as vinyl ester styrene, VES) (Morgan and Bostick, 1992; Del Cul, et al., 1991). Volumetric loading efficiencies for the stabilization of spent anion exchange resin in waste forms are $\sim 50 \%$ for grout and $\sim 90 \%$ for VES (Morgan and Bostick, 1992). Assuming disposal of spent Dowex ${ }^{\mathrm{TM}} 1-\mathrm{X} 8$ resin laden with $\sim 10 \mathrm{mg}{ }^{99} \mathrm{Tc}$ per $\mathrm{cm}^{3}$ (or $\sim 170 \mathrm{Ci} / \mathrm{m}^{3}$; see section 4.2 ), the stabilized waste forms would contain $\sim 85$ $\mathrm{Ci} / \mathrm{m}^{3}$ (grout) to $\sim 150 \mathrm{Ci} / \mathrm{m}^{3}$ (VES), well in excess of the draft criterion of $5.5 \mathrm{E}-06 \mathrm{Ci} / \mathrm{m}^{3}$ for disposal of ${ }^{99} \mathrm{Tc}$ as Class LII solid waste at the Oak Ridge Reservation (Arnold, et al., 1994). 



\section{REFERENCES}

1. Y. Albinsson, B. Christiansen-Saetmark, I. Engkvist, and W. Johansson, 1991. "Transport of Actinides and Technetium Through a Bentonite Backfill Containing Small Quantities of Iron or Copper," Radiochim. Acta, 52-53(Pt. 1), 283.

2. W. D. Arnold, D. T. Bostick, M. W. Burgess, P. A. Taylor, J. J. Perona, and T. E. Kent, 1994. Laboratory Development of Methods for Centralized Treatment of Liquid Low-Level Waste at Oak Ridge National Laboratory, Martin Marietta Energy Systems Report ORNL/TM-12786.

3. D. E. Beck, W. D. Bostick, D. H. Bunch, R. L. Fellows, P. E. Osborne, G. F. Sellers and K. Bowser, 1995. Comparison of Metal Wool and Selected Organic Resins for the Removal of Mercury (II) or Technetium (VII) from Contaminated Solutions, submitted for presentation at Ninth Symposium on Separation Science and Technology for Energy Applications, Gatlinburg TN, October 22-26, 1995.

4. W. D. Bostick, P. E. Osborne, G. D. Del Cul, and D. W. Simmons, 1995. Treatment of Aqueous Solutions Contaminated with Technetium-99 Originating from Uranium Enrichment Activities: Final Report, Martin Marietta Energy Systems Report K/TCD-1120.

5. V. Fowler, 1995. "Preliminary Calculation of Tc-99 Content in LLLW," Internal Correspondence to T. E. Kent, May, 1995. Martin Marietta Energy Systems, Inc., Oak Ridge, Tenn.

6. L. E. Deacon and M. J. Greiner, 1982. Technology Transfer: Ion Exchange Resins for Technetium-99 Removal from X-705 Raffinates, Goodyear Atomic Corporation Report GAT-2010.

7. G. D. Del Cul and W. D. Bostick, 1995. "Simple Method for Technetium Removal from Aqueous Solutions," Nucl. Technol. 101(1), 161.

8. G. D. Del Cul, I. L. Morgan, W. D. Bostick, and P. E. Osborne, 1991. Grout-Based Waste Forms for the Solidification of Anion Exchange Resins: Final Report, K/TCD-1004, Martin Marietta Energy Systems, Inc., Oak Ridge, Tenn.

9. T. E. Gangwer, M. Goldstein, and K. K. S. Pillay, 1977. Radiation Effects on Ion Exchange Materials, BNL-50781, Brookhaven National Laboratory, Upton, Long Island, N.Y.

10. E. H. Huffman, R. L. Oswalt, and I. A. Williams, 1956. Anion-Exchange Separations of Molybdenum and Technetium and of Tungsten and Rhenium, Inorg. Nucl. Chem., 3, 49.

11. M. Kawasaki, T. Omori, and K. Hasegawa, 1993. "Adsorption of Pertechnetate on an Anion Exchange Resin," Radiochim. Acta 63, 53.

12. E. D. Kiseleva, A. A. Oblova, A. F. Fuzina, and Spitzen, 1962. Study of the Mechanism of Sorption of the Pertechnetate Ion by Anion-Exchange Resins, Dokl. Akad. Nauk SSSR, 198, 1.

13. D. F. McGinnes and A. Dyer, 1992. "Disposal of Organic Ion Exchange Resins Contaminated with Technetium-99," pp. 1557-62 in R. G. Post, ed., Waste Management '92, Vol. 2. 

14. N. Momoshima, M. Sayad, and Y. Takashima, 1983. "Analytical Procedure for Technetium-99 in Seawater by ICP-MS," Radiochim. Acta 63, 73.

15. I. L. Morgan and W. D. Bostick, 1992. "Performance Testing of Grout-Based Waste Forms for the Solidification of Anion Exchange Resins," pp. 133-145 in Amer. Soc. Test. Mater., Std. Publ. No. 1123.

16. A. Mustaq, 1993. "Sorption Behavior of Carrier-Free Technetium-99 on Zinc Dust," Sep. Sci. Technol., 28(9), 1743.

17. M. Pourbaix, 1966. Atlas of Electrochemical Equilibria in Aqueous Solutions, Pergamon Press, Oxford.

18. F. P. Roberts, F. M. Smith, and E. J. Wheelwright, 1962. Recovery and Purification of Technetium-99 from Neutralized Purex Waste, General Electric Company Report HW-SA-2581.

19. N.C. Schroeder, et al., 1993. Technetium Partitioning for the Hanford Tank Waste Remediation System: Adsorption and Extraction of Technetium from Double-Shell Slurry Waste Simulant, LAUR-93-4092, Los Alamos National Laboratory, Los Alamos, N.M.

20. N. C. Schroeder, et al., 1994. Technetium Partitioning for the Hanford Tank Waste Remediation System: Sorption and Extraction of Technetium from Simple Caustic Solutions, LAUR-94-62, Los Alamos National Laboratory, Los Alamos, N.M.

21. N. C. Schroeder, et al., 1995. Technetium Partitioning for the Hanford Tank Waste Remediation System: Sorption of Technetium from DSS and DSSF-7 Waste Simulants Using Reillex ${ }^{\mathrm{TM}}$ HPQ Resin, LAUR-95-40, Los Alamos National Laboratory, Los Alamos, N.M. 


\section{DISTRIBUTION LIST \\ INTERNAL (LMES/LUMS)}

$\begin{array}{cl}1 . & \text { F. A. Anderson } \\ 2 . & \text { D. E. Beck } \\ 3 . & \text { J. B. Berry } \\ 4 . & \text { M. W. Burgess } \\ 5 . & \text { W.D. Bond } \\ 6 . & \text { D. A. Bostick } \\ 7 . & \text { W. D. Bostick } \\ 8 . & \text { K. T. Bowser } \\ 9 . & \text { D. D. Brickeen } \\ 10 . & \text { T. K. Broussard } \\ 11 . & \text { D. H. Bunch } \\ 12 . & \text { M. W. Burgess } \\ 13 . & \text { C. H. Byers } \\ 14 . & \text { J. L. Clausen } \\ 15 . & \text { E. D. Collins } \\ 16 . & \text { J. L. Collins } \\ 17 . & \text { T. B. Conley } \\ 18 . & \text { A. G. Croff } \\ 19 . & \text { N. H. Cutshall } \\ 20 . & \text { D. L. Daugherty } \\ 21 . & \text { D. J. Davidson } \\ 22 . & \text { L. E. Deacon } \\ 23 . & \text { G. D. DelCul } \\ 24 . & \text { S. M. PePaoli } \\ 25 . & \text { A. Dieffendorf } \\ 26 . & \text { J. W. Douthit } \\ 27 . & \text { B. Z. Egan } \\ 28 . & \text { T. O. Early } \\ 29 . & \text { R. C. Edwards } \\ 30 . & \text { R. L. Fellows } \\ 31 . & \text { J. L. Frazier } \\ 32 . & \text { V. L. Fowler } \\ 33 . & \text { R. K. Genung } \\ 34 . & \text { T. M. Gilliam } \\ 35 . & \text { G. A. Gillis } \\ 36 . & \text { P. A. Gouriex } \\ 37 . & \text { B. B. Gus } \\ 38 . & \text { R. L. Hallman } \\ 39 . & \text { R. L. Higgins }\end{array}$

$\begin{array}{ll}40 . & \text { J. R. Hightower } \\ 41 . & \text { D. P. Hoffmann } \\ 42 . & \text { C. M. Kendrick } \\ 43 . & \text { T. E. Kent } \\ 44 . & \text { P. G. Kirk } \\ 45 . & \text { K. T. Klasson } \\ 46 . & \text { D. A. Kucsmas } \\ 47 . & \text { D. D. Lee } \\ 48 . & \text { S. Y. Lee } \\ 49 . & \text { D. K. Little } \\ 50 . & \text { R. C. Mason } \\ 51 . & \text { A. J. Mattus } \\ 52 . & \text { E. W. McDaniel } \\ 53 . & \text { C. P. McGinnis } \\ 54 . & \text { D. R. McTaggart } \\ 55 . & \text { B. A. Moyer } \\ 56 . & \text { L. E. McNeese } \\ 57 . & \text { P. E. Osborne } \\ 58 . & \text { J. R. Parron, Jr. } \\ 59 . & \text { B. D. Patton } \\ 60 . & \text { A. S. Quist (3) } \\ 61 . & \text { W. L. Richards } \\ 62 . & \text { S. M. Robinson } \\ 63 . & \text { S. T. Ruddell } \\ 64 . & \text { A. J. Saraceno } \\ 65 . & \text { C. B. Scott } \\ 66 . & \text { G. F. Sellers } \\ 67 . & \text { J. L. Shoemaker } \\ 68 . & \text { D. W. Simmons } \\ 69 . & \text { S. H. Skaggs } \\ 70 . & \text { C. M. Smith } \\ 71 . & \text { A. J. Story } \\ 72 . & \text { P. A. Taylor } \\ 73 . & \text { W. T. Thompson } \\ 74 . & \text { J. R. Tragalka } \\ 75 . & \text { J. F. Walker } \\ 76 . & \text { J. S. Watson } \\ & \\ \text { Central Research Library } \\ & \\ 56\end{array}$

EXTERNAL

D. Marozas, Sandia National Laboratory, Alburquerque, NM 87185-0719

Office of Scientific and Technical Information, Post Office Box 62, Oak Ridge, TN 37831

N. Schroeder, Los Alamos National laboratory, MS-J514, Los Alamos, NM 87545 